\title{
THE EFFECT OF SERUM FROM INSULIN-RESISTANT CASES ON THE COMBINATION OF INSULIN WITH THE RAT DIAPHRAGM ${ }^{1}$
}

\author{
By JULIAN B. MARSH AND NIELS HAUGAARD
}

\author{
(From the John Herr Musser Department of Research Medicine, University of Pennsylvania, \\ Philadelphia, Pa.)
}

(Submitted for publication August 7, 1951; accepted September 10, 1951)

Insulin resistance is currently believed to be associated with insulin-neutralizing substances in the blood. Lowell (1), employing the mouse convulsion assay for insulin, has shown that the injection of mixtures of insulin and serum from insulin-resistant diabetic patients into mice caused a significantly smaller incidence of convulsive symptoms than the injection of the same amounts of insulin alone. He points out, however, that the quantitative interpretation of these experiments is difficult because of the variations of the response of the animals to insulin and the nonspecific effects of the injection of serum. It would be desirable, therefore, to employ a method for the determination of insulin-inactivating properties of serum which does not involve the administration of insulin-serum mixtures to the intact animal. In the course of our recent work on the chemical combination of insulin with the rat diaphragm $(2,3)$ it became apparent that this technique would provide a method for the detection of insulin-inactivating substances in any solution. Accordingly, we have tested serum from normal, diabetic, and insulin-resistant subjects and found, in confirmation of the results of Lowell, that serum from insulin-resistant patients has the property of opposing the action of insulin.

\section{METHODS}

In our procedure (2), the synthesis of glycogen from glucose by paired rat hemi-diaphragms is measured. Insulin is added to the appropriate dilution of serum at $25^{\circ} \mathrm{C}$., and after five minutes one of the hemi-diaphragms is placed in this solution for an additional one minute. The paired control hemi-diaphragm is placed for one minute in serum to which no insulin has been added. Both hemidiaphragms are then washed twice for 30 seconds each in

1 The work reported in this paper was supported in part by grants from the National Institutes of Health, United States Public Health Service, and the Insulin Grants Committee of the Lilly Research Laboratories.
$25 \mathrm{ml}$. phosphate-saline medium and transferred to vessels containing medium of the following composition; $0.087 \mathrm{M} \mathrm{NaCl}, 0.005 \mathrm{M} \mathrm{MgCl}_{2}, 0.040 \mathrm{M}$ sodium phosphate, and $0.4 \%$ glucose, $\mathrm{pH} 6.8$. The vessels are gassed with oxygen and shaken in a water bath at $38^{\circ} \mathrm{C}$. for $90 \mathrm{~min}$ utes. The difference in the extent of glycogen synthesis during the period of equilibration is a measure of the insulin effect. Since the amount of insulin combining with the diaphragm as measured by the effect on glycogen synthesis has been shown to vary in a regular manner with the insulin concentration during the one minute exposure (3), it is evident that a change in the effective concentration of insulin brought about by the addition of serum should be measurable by this method. It should be pointed out, however, that the method suffers from severe limitations caused by the biological variability of the response of the diaphragm to insulin and to errors necessarily introduced by the many manipulations involved. For each assay several experiments are carried out and the mean insulin effect recorded. We believe that decreases in insulin concentration of $50 \%$ or more should be clearly demonstrable by this method.

\section{RESULTS}

It may be seen from Table I that at an insulin concentration of 0.1 unit per ml., the insulin effect is lower when the diaphragm is exposed to an insulin-serum mixture than when serum is omitted. However, sera from normal persons and non-resistant diabetic patients do not differ significantly in their ability to lower the effective concentration of insulin.

In three cases of insulin resistance, requiring 300 to 800 units per day, the insulin effect after incubation with serum of dilution $1: 1$ was not significantly different from zero (cases I, II, and III, Table I). Where the insulin resistance was mild as in cases IVa, V, and VI, the insulin effects were not significantly lower than in the presence of normal serum. ${ }^{2}$

2 We should like to express our thanks to the physicians who kindly made available the sera used in these experiments. Case I was a patient of Dr. Norman Schnee- 
TABLE I

The effect of sera from normal and insulin-resistant individuals on the combination of insulin with rat diaphragm

The serum was diluted with phosphate-saline medium as indicated below and incubated for five minutes at room temperature with 0.1 unit of insulin per $\mathrm{ml}$. A normal rat hemi-diaphragm was added for one minute, washed and allowed to synthesize glycogen for 90 minutes. The control hemi-diaphragm was treated in the same manner, except for the omission of insulin. The insulin effect is the difference in final glycogen content of the two hemidiaphragms.

\begin{tabular}{|c|c|c|c|c|}
\hline Source of serum & $\begin{array}{l}\text { Insulin } \\
\text { require- } \\
\text { ment }\end{array}$ & $\begin{array}{l}\text { Dilu- } \\
\text { tion }\end{array}$ & $\begin{array}{l}\text { No. of } \\
\text { expts. }\end{array}$ & $\begin{array}{l}\text { Insulin effect } \\
\text { on glycogen } \\
\text { synthesis, } \\
\text { micromoles } \\
\text { (glucose equiv.) } \\
\text { per gram } \\
\text { Mean } \pm \text { SEM }\end{array}$ \\
\hline & $\begin{array}{c}\text { (units/ } \\
\text { day) }\end{array}$ & & & \\
\hline No serum present & - & & 75 & $8.3 \pm 0.52$ \\
\hline Normal persons & & $1: 1$ & 11 & $5.6 \pm 0.92$ \\
\hline Mild diabetics & $0-20$ & $1: 1$ & 6 & $5.3 \pm 1.05$ \\
\hline $\begin{array}{l}\text { severe } \\
\text { Case I }\end{array}$ & 800 & $1: 1$ & 5 & $0.6 \pm 0.67$ \\
\hline & & $1: 3$ & 5 & $2.1 \pm 1.26$ \\
\hline Case II & 600 & $1: 1$ & 5 & $0.5 \pm 0.98$ \\
\hline & 300 & $1: 10$ & $\begin{array}{l}6 \\
5\end{array}$ & $5.0 \pm 1.41$ \\
\hline Case 111 (a) & 300 & $\begin{array}{l}1: 1 \\
1: 3\end{array}$ & $\begin{array}{l}5 \\
5\end{array}$ & $\begin{array}{l}2.2 \pm 0.98 \\
4.7 \pm 1.15\end{array}$ \\
\hline $\begin{array}{c}\text { (b) } \\
\text { Insulin-resistant, } \\
\text { mild }\end{array}$ & 170 & $1: 1$ & 4 & $4.0 \pm 1.75$ \\
\hline Case IV (a) & 200 & $1: 1$ & 5 & $3.2 \pm 1.09$ \\
\hline Case $\mathrm{V}^{\text {(b) }}$ & 20 & $1: 1$ & 4 & $7.0 \pm 1.46$ \\
\hline Case VI & $\begin{array}{l}150 \\
150\end{array}$ & $\begin{array}{l}1: 1 \\
1: 1\end{array}$ & $\begin{array}{l}4 \\
3\end{array}$ & $\begin{array}{l}4.8 \pm 0.71 \\
5.1 \pm 2.25\end{array}$ \\
\hline
\end{tabular}

The samples of serum from the more severe cases of insulin resistance were studied in different dilutions as indicated in Table I. It is evident that the more dilute solutions are less effective in lowering the concentration of insulin.

Samples of serum from cases III and IV were obtained and studied at different times during the observation of the patients. The insulin requirements of case III were of the same order of magnitude when the two samples were taken and there were no significant differences between the activity of the two samples. In case IV, however, the second sample was taken at a time when no insulin resistance was observed and the insulin effect was significantly higher than with the first sample.

berg of Mount Sinai Hospital, Philadelphia, Pa. Serum from case II was obtained from Dr. Leon S. Smelo of the Medical Diagnostic Clinic, Birmingham, Ala. Serum from case III was obtained from Dr. W. Wallace Dyer of the Hospital of the University of Pennsylvania, Philadelphia, $\mathrm{Pa}$. The sera from the patients with mild insulin resistance were from the Hospital of the University of Pennsylvania. Case III has been reported by Spoont and Dyer (4).
Table II shows the results of a more extensive study carried out with serum from a patient of Dr. John Howard of the Johns Hopkins Hospital. $^{3}$ During the course of this man's illness he required as much as 6,000 units of insulin per day to control his diabetes. All of the samples of serum studied except the last which was taken after recovery of the patient possesed insulininactivating properties at a dilution of $1: 4$. The first sample taken at the height of the resistance to insulin was active at a dilution of $1: 4$ and $1: 10$. Even at a dilution of $1: 100$ there appeared to be some activity present since the mean insulin effect was significantly lower than in the absence of serum (Table I). The patient was treated with ACTH because of the allergic phenomena present and in the course of a week the resistance was improved, with a daily insulin requirement of less than 500 units. Serum drawn at this time still showed insulin-inactivating ability at a dilution of $1: 4$.

Except for the demonstration that the last sample of serum taken at a time when the patient had recovered completely from the insulin resistance did not possess any insulin-inactivating properties, we have not been able to observe any consistant correlation between the activity of the serum and the clinical course of the patient. In

${ }^{3} \mathrm{We}$ should like to express our appreciation to Drs. John E. Howard and Ernest Brown of Johns Hopkins Hospital for sending us these samples of serum from this unusual case of insulin resistance.

TABLE II

The effect of serum from a severe case of insulin resistance on the combination of insulin with rat diaphragm

(Procedure was the same as that indicated in Table I)

\begin{tabular}{|c|c|c|c|c|c|}
\hline $\begin{array}{c}\text { Serum } \\
\text { no. }\end{array}$ & Date & $\begin{array}{l}\text { Insulin } \\
\text { requirement }\end{array}$ & $\begin{array}{c}\text { Dilution } \\
\text { of } \\
\text { serum }\end{array}$ & $\begin{array}{l}\text { No. of } \\
\text { expts. }\end{array}$ & $\begin{array}{c}\text { Insulin effect, } \\
\text { micromoles } \\
\text { (glucose equiv.) } \\
\text { per gram } \\
\text { Mean } \pm \text { SEM }\end{array}$ \\
\hline & & (units/day) & & & \\
\hline 1 & $7 / 22 / 50$ & $3,000-6,000$ & $\begin{array}{l}1: 4 \\
1: 10 \\
1: 100\end{array}$ & $\begin{array}{r}4 \\
9 \\
10\end{array}$ & $\begin{array}{l}2.0 \pm 0.50 \\
1.7 \pm 1.36\end{array}$ \\
\hline 2 & $9 / 15 / 50$ & 1,500 & $1: 4$ & 4 & $2.6 \pm 0.74$ \\
\hline 3 & $9 / 28 / 50$ & $600^{*}$ & $1: 4$ & 5 & $1.9 \pm 1.42$ \\
\hline 4 & $10 / 2 / 50$ & $100^{*}$ & $1: 4$ & 4 & $0.1 \pm 2.80$ \\
\hline 5 & $10 / 7 / 50$ & $0^{*}$ & $1: 4$ & 4 & $2.2 \pm 0.50$ \\
\hline 6 & $10 / 20 / 50$ & $0^{*}$ & $1: 4$ & 5 & $1.7 \pm 1.53$ \\
\hline & & & $\begin{array}{l}1: 10 \\
1: 100\end{array}$ & $\begin{array}{l}7 \\
5\end{array}$ & $\begin{array}{l}2.8 \pm 2.27 \\
5.6 \pm 1.82\end{array}$ \\
\hline 7 & $1 / 9 / 51$ & $0-20$ & $1: 4$ & 4 & $6.9 \pm 0.83$ \\
\hline
\end{tabular}

* Patient was receiving ACTH therapy. 
the dilutions of $1: 4$ the samples of the serum all showed the presence of insulin-inactivating substances. A better quantitative comparison might have been achieved by determining the highest dilution at which each serum still exhibited insulin-inactivating properties. Such a study, however, would require a very large number of experiments and would at best be only semiquantitative due to the limitations of the assay method.

It is interesting that samples 5 and 6 still exhibited insulin-inactivating activity although the insulin resistance at that time had been overcome. The possibility suggests itself that the activity at this stage might be a reflection of the ACTH therapy.

A detailed discussion of the illness of this patient and of the results of the treatment with ACTH has been published by Howard (5).

A number of experiments were carried out in order to obtain some information about the nature of the factor in serum responsible for the insulininactivating property. It was found that the inactivating property of serum at a given dilution could be overcome by raising the concentration of insulin. A mixture of sera from samples 2 and 3 (Table II) in a dilution of $1: 4$ was used. Both these samples have been shown to inactivate 0.1 unit of insulin per $\mathrm{ml}$. at this dilution. It was found that when the concentration of insulin was raised to 1 unit per $\mathrm{ml}$. an insulin effect of 12.6 \pm 4.12 micromoles per gram was obtained ( $\mathrm{N}$ $=4$ ). This is not significantly different from the insulin effect at this concentration of insulin in the absence of serum. It is apparent from this experiment and from the experiments with different dilutions of serum and constant insulin concentration that the extent of the insulin effect is a function of the relative amounts of serum and insulin.

We have studied whether treatment of the diaphragm with serum from an insulin-resistant patient will make it refractory to the subsequent action of insulin. Sample 1 (Table II) was used for the experiment. This sample of serum completely abolished the insulin effect in a dilution of $1: 10$ and even appeared to have some activity at a dilution 1:100. One hemi-diaphragm was equilibrated in this serum at a $1: 4$ dilution for five minutes at $38^{\circ} \mathrm{C}$. The control hemi-diaphragm was equilibrated in medium for the same length of time. Both diaphragms were then immersed in an insulin solution at a concentration of 0.1 unit per $\mathrm{ml}$. for one minute, washed and allowed to synthesize glycogen for $90 \mathrm{~min}$ utes at $38^{\circ} \mathrm{C}$. In five experiments there was no significant difference between the final glycogen contents of the paired hemi-diaphragms indicating that the treatment of the diaphragm with serum had not influenced its ability to synthesize glycogen or respond to insulin.

It does not appear that hyperglycemia by itself is a factor in the production of insulin-inactivating substances. No insulin-inactivating properties could be demonstrated in a sample of serum from a patient with a brain lesion resulting in excessive hyperglycemia $(1,500 \mathrm{mg} . \%)$. It was also noted that the blood sugar concentrations in the samples of serum from the insulin-resistant cases studied varied considerably and did not bear any relation to the ability of the serum to inactivate insulin. The presence of glucose during the exposure to insulin has been shown in previous experiments to have no effect on the combination of insulin with the diaphragm (2).

\section{DISCUSSION}

The experiments reported here indicate that the technique involved in studying the combination of insulin with the isolated rat diaphragm provides a method for the estimation of insulinneutralizing substances in serum or other solutions. By this means, we have shown that sera from normal and diabetic human subjects contain significant amounts of such substances and that the serum of insulin-resistant individuals contains excessive amounts. Presumably, these substances combine with or inactivate some or all of the added insulin during the five minute incubation period before the diaphragm is exposed to the insulin-serum mixture.

An alternative explanation of these experimental results is that some substance in the serum from insulin-resistant individuals is capable of combining with the diaphragm during the one minute incubation period rendering it less susceptible to the action of insulin. Such an effect has been obtained in experiments with pitui- 
tary extract (6). However, our negative results in an attempt to demonstrate an action of serum itself on the diaphragm lead us to believe that substances present in the serum combine with or inactivate insulin in the serum-insulin mixture. The experiments of Lowell (1) are also best interpreted in this light.

The origin and chemical nature of the active principle demonstrated in serum from insulinresistant individuals remain a matter for speculation. It is possible that a reaction of the nature of an antigen-antibody combination takes place. If such is the case, it should be possible to demonstrate a quantitative relationship between the ratio of serum to insulin in the serum-insulin mixture used and the ability to prevent the action of insulin on the diaphragm.

It would also be of great importance to determine whether the effects obtained with serum are dependent on the type of insulin used, particularly whether the insulin-inactivating properties of serum are found when human insulin is used or whether it is only demonstrable with insulin obtained from animal sources.

It is of interest here to note that Brown (7) has been able to demonstrate that serum from the insulin-resistant patient of Dr. Howard had the property in high dilutions of causing the agglutination of insulin-coated polystyrene particles. This phenomenon was observed to a greater or smaller extent with all the samples of serum in Table II except the last. These results are, therefore, in agreement with our findings since only with the last sample of serum did we fail to demonstrate the ability to lower the effect of insulin on the diaphragm.

The ability of normal human serum to lower the effective concentration of insulin is interesting and leads one to speculate whether insulin may not normally be present in the blood in a form combined with some serum component.

\section{SUM MARY}

The ability of human serum to influence the combination of insulin with the isolated rat diaphragm has been studied. The combination of insulin with the diaphragm, as measured by its effect on glycogen synthesis, was found to be significantly decreased in the presence of serum from normal or diabetic individuals. We have concluded from this that serum contains substances which combine with or inactivate insulin. Serum from insulin-resistant patients appears to contain greatly increased amounts of such substances.

Experiments on the combination of insulin with tissue offer interesting possibilities in the study of the phenomenon of insulin resistance.

\section{REFERENCES}

1. Lowell, F. C., Immunologic studies in insulin resistance. II. The presence of a neutralizing factor in the blood exhibiting some characteristics of an antibody. J. Clin. Invest., 1944, 23, 233.

2. Stadie, W. C., Haugaard, N., Marsh, J. B., and Hills, A. G., The chemical combination of insulin with muscle (diaphragm) of normal rat. Am. J. M. Sc., 1949, 218, 265.

3. Stadie, W. C., Haugaard, N., and Marsh, J. B., Factors influencing the combination of insulin with muscle from normal rats. J. Biol. Chem., 1951, $189,53$.

4. Spoont, S., and Dyer, W. W., Insulin resistance associated with local and general allergy to insulin. J.A.M.A., 1951, 145, 558.

5. Howard, J. E., in discussion on Margen, S., Michaels, G. D., Boling, L. A., and Kinsell, L. W., Hormonal regulation of fat metabolism. II. Effects of ACTH and certain steroid hormones upon the utilization of infused aceto-acetate and octonoic acid, in Proceedings of the Second Clinical ACTH Conference, edited by Mote, J. R. The Blakiston Co., New York, 1951, Vol. I., Chap. 32, p. 318.

6. Stadie, W. C., Haugaard, N., Hills, A. G., and Marsh, J. B., Hormonal influences on the chemical combination of insulin with rat muscle (diaphragm). Am. J. M. Sc., 1949, 218, 275.

7. Brown, E. C., Jr., Personal communication. 